\title{
Comparative energy content and amino acid digestibility of barley obtained from diverse sources fed to growing pigs
}

\author{
Hong Liang Wang ${ }^{1, a}$, Meng Shi ${ }^{1, a}$, Xiao Xu ${ }^{1}$, Xiao Kang Ma ${ }^{1}$, Ling Liu ${ }^{1}$, and Xiang Shu Piao ${ }^{1, *}$
}

* Corresponding Author: Xiang Shu Piao Tel: +86-15901013490, Fax: +86-010-62733688,

E-mail: piaoxsh@cau.edu.cn

'State Key Laboratory of Animal Nutrition, Ministry of Agriculture Feed Industry Centre, China Agricultural

University, Beijing 100193, China

a These authors contributed equally to this work. Submitted Oct 9, 2016; Revised Nov 14, 2016; Accepted Dec 29, 2016
Objective: Two experiments were conducted to determine the content of digestible energy (DE) and metabolizable energy (ME) as well as the apparent ileal digestibility (AID) and standardized ileal digestibility (SID) of crude protein (CP) and amino acids (AA) in barley grains obtained from Australia, France or Canada.

Methods: In Exp. 1, 18 growing barrows (Duroc $\times$ Landrace $\times$ Yorkshire; $31.5 \pm 3.2 \mathrm{~kg}$ ) were individually placed in stainless-steel metabolism crates $(1.4 \times 0.7 \times 0.6 \mathrm{~m})$ and randomly allotted to 1 of 3 test diets. In Exp. 2, eight crossbred pigs (30.9 $\pm 1.8 \mathrm{~kg}$ ) were allotted to a replicate $3 \times 4$ Youden Square designed experiment with three periods and four diets. Two pigs received each diet during each test period. The diets included one nitrogen-free diet and three test diets. Results: The relative amounts of gross energy (GE), CP, and all AA in the Canadian barley were higher than those in Australian and French barley while higher concentrations of neutral detergent fiber, acid detergent fiber, total dietary fiber, insoluble dietary fiber and $\beta$-glucan as well as lower concentrations of GE and ether extract were observed in the French barley compared with the other two barley sources. The DE and ME as well as the SID of histidine, isoleucine, leucine and phenylalanine in Canadian barley were higher $(\mathrm{p}<0.05)$ than those in French barley but did not differ from Australian barley.

Conclusion: Differences in the chemical composition, energy content and the SID and AID of AA were observed among barley sources obtained from three countries. The feeding value of barley from Canada and Australia was superior to barley obtained from France which is important information in developing feeding systems for growing pigs where imported grains are used.

Keywords: Barley; Digestible Energy; Metabolizable Energy; Amino Acid; Digestibility; Growing Pigs

\section{INTRODUCTION}

Barley is grown in many areas including Europe, Canada, the United States, and Australia, where it is primarily used for malt and livestock feeding [1]. Total global production of barley is approximately 140 million tons per year [2], which ranks 4th in terms of global grain production after corn, rice, and wheat. Barley has higher concentrations of amino acids (AA) and fiber and lower concentrations of starch compared with corn, but the digestibility of the starch and AA in barley is lower than their digestibility in wheat and corn $[3,4]$.

As a result of volatility in corn and wheat prices in Chinese market, feed manufacturers have shown interest in using imported barley as an alternative energy source to be incorporated into pig diets in situations where there is a price advantage for barley over corn and wheat. For that purpose, it is essential to have information on the energy content and ileal digestibility of AA to obtain the productive advantage of this type of formulation. We hypothesized that the chemical composition of barley samples from different countries are not similar and thus may have varied 
$\mathrm{DE}$ and ME content as well as AA digestibility. Therefore, the objectives of the current study were to determine the energy content and AA digestibility of these imported barley samples and to have a good knowledge of their nutritional value to ensure an accurate feed formulation.

\section{MATERIALS AND METHODS}

The protocol for this experiment was approved by the Institutional Animal Care and Use Committee of China Agricultural University (Beijing, China). The study was conducted in the Swine Nutrition Research Center of the National Feed Engineering Technology Research Center (Chengde, Hebei, China).

\section{Sources of ingredients}

Imported hulled barley from Australia, France and Canada were obtained from the Nantong Port in the Jiangsu Province of China.

Table 1. Analyzed chemical and amino acids composition of barleys used in the experiment ( $\%$ as-fed basis) $)^{1)}$

\begin{tabular}{|c|c|c|c|}
\hline \multirow{2}{*}{ Item } & \multicolumn{3}{|c|}{ Source of barley } \\
\hline & Australia & France & Canada \\
\hline Dry matter & 0.89 & 0.89 & 0.88 \\
\hline Gross energy (MJ/kg) & 16.42 & 16.25 & 16.30 \\
\hline Starch & 51.51 & 48.64 & 49.22 \\
\hline Neutral detergent fiber & 17.09 & 18.97 & 18.44 \\
\hline Acid detergent fiber & 5.24 & 5.60 & 5.05 \\
\hline Total dietary fiber & 18.68 & 22.46 & 20.20 \\
\hline Insoluble dietary fiber & 15.91 & 17.31 & 16.75 \\
\hline$\beta$-glucan & 4.27 & 4.80 & 3.93 \\
\hline Crude protein & 9.07 & 9.14 & 10.12 \\
\hline Ether extract & 2.68 & 2.23 & 2.40 \\
\hline Ash & 2.48 & 2.74 & 2.49 \\
\hline Calcium & 0.02 & 0.07 & 0.01 \\
\hline Total phosphorus & 0.27 & 0.27 & 0.28 \\
\hline \multicolumn{4}{|c|}{ Indispensable amino acids } \\
\hline Arginine & 0.46 & 0.44 & 0.48 \\
\hline Histidine & 0.16 & 0.15 & 0.17 \\
\hline Isoleucine & 0.32 & 0.29 & 0.34 \\
\hline Leucine & 0.71 & 0.65 & 0.74 \\
\hline Lysine & 0.37 & 0.35 & 0.39 \\
\hline Methionine & 0.13 & 0.11 & 0.12 \\
\hline Phenylalanine & 0.46 & 0.43 & 0.49 \\
\hline Threonine & 0.34 & 0.32 & 0.35 \\
\hline Tryptophan & 0.12 & 0.10 & 0.11 \\
\hline Valine & 0.50 & 0.46 & 0.53 \\
\hline \multicolumn{4}{|l|}{ Dispensable amino acids } \\
\hline Alanine & 0.46 & 0.38 & 0.48 \\
\hline Asparagine & 0.60 & 0.56 & 0.61 \\
\hline Cysteine & 0.18 & 0.17 & 0.20 \\
\hline Glutamine & 1.90 & 1.82 & 2.12 \\
\hline Glycine & 0.40 & 0.38 & 0.41 \\
\hline Proline & 0.97 & 0.92 & 1.04 \\
\hline Serine & 0.40 & 0.37 & 0.41 \\
\hline Tyrosine & 0.21 & 0.22 & 0.25 \\
\hline
\end{tabular}

${ }^{1)}$ Analysis conducted in duplicate.
The chemical and AA composition of the barleys are presented in Table 1.

\section{Experiment 1}

Experiment 1 was conducted to determine the digestible energy (DE) and metabolizable energy (ME) content of the barley obtained from the three sources. Eighteen (Duroc $\times$ Landrace $\times$ Yorkshire) growing barrows $(31.5 \pm 3.2 \mathrm{~kg})$ were randomly allotted to 1 of 3 test diets (Table 2). Each diet was fed to 6 barrows housed in individual metabolism crates for a 10-d acclimation period followed by a $5-\mathrm{d}$ total but separate collection of feces and urine. The test diets were formulated to contain $96.9 \%$ of one of the three barley sources and $3.1 \%$ vitamins and minerals. Vitamins and minerals were supplied at a level estimated to meet or exceed the nutrient requirements for growing pigs recommended by the NRC [5]. The analyzed composition of the experimental diets is presented in Table 3.

The pigs were individually placed in stainless-steel metabolism crates $(1.4 \times 0.7 \times 0.6 \mathrm{~m})$ equipped with a water nipple and a feeding trough and housed in an environmentally controlled room $\left(22^{\circ} \mathrm{C} \pm 2^{\circ} \mathrm{C}\right)$. The pigs were fed $4 \%$ of their body weight (BW) each day [6]. The daily feed allotment was divided into two equal sized meals provided at 08:30 h and 15:30 h. Pigs had ad libitum access to water throughout the experiment. Feed refusals and spillage were collected, dried, weighed and recorded.

Individual pig BW was obtained at the beginning of the experiment. Feces were placed in plastic bags (one bag per pig) as soon as they appeared in the metabolism crates and were immediately stored at $-20^{\circ} \mathrm{C}$. A bucket containing $50 \mathrm{~mL}$ of $6 \mathrm{~N} \mathrm{HCl}$ was used to collect urine. Each day, the volume of collected urine was measured and $10 \%$ of the daily urinary collection was filtered and transferred into a screw-capped bottle and then stored at

Table 2. Ingredient composition of the experimental diets (\% as-fed basis)

\begin{tabular}{|c|c|c|c|}
\hline \multirow{2}{*}{ Ingredient } & \multirow{2}{*}{$\begin{array}{c}\text { Exp. } 1 \\
\text { Test diets }\end{array}$} & \multicolumn{2}{|r|}{ Exp. 2} \\
\hline & & Test diets & Nitrogen-free diet \\
\hline Barley & 96.9 & 96.6 & - \\
\hline Cornstarch & - & - & 68.9 \\
\hline Soybean oil & - & - & 3.0 \\
\hline Sucrose & - & - & 20.0 \\
\hline Cellulose acetate $^{1)}$ & - & - & 4.0 \\
\hline Limestone & 0.6 & 0.6 & 1.0 \\
\hline Dicalcium phosphate & 1.7 & 1.7 & 1.6 \\
\hline Chromic oxide & - & 0.3 & 0.3 \\
\hline Salt & 0.3 & 0.3 & 0.3 \\
\hline Potassium carbonate & - & - & 0.3 \\
\hline Magnesium oxide & - & - & 0.1 \\
\hline Vitamin and mineral premix ${ }^{2)}$ & 0.5 & 0.5 & 0.5 \\
\hline
\end{tabular}

1) Produced by Sinopharm Chemical Reagent Company Limited (Shanghai, China).

2) Premix provided the following per $\mathrm{kg}$ of complete diet for growing pigs: vitamin $A$, 5,512 IU; vitamin D3, 2,200 IU; vitamin E, 64 IU; vitamin $\mathrm{K}_{3}, 2.2 \mathrm{mg}$; vitamin $\mathrm{B}_{12}, 27.6$ $\mu \mathrm{g}$; riboflavin, $5.5 \mathrm{mg}$; pantothenic acid, $13.8 \mathrm{mg}$; niacin, $30.3 \mathrm{mg}$; choline chloride, $551 \mathrm{mg} ; \mathrm{Mn}, 40 \mathrm{mg}\left(\mathrm{MnSO}_{4}\right) ; \mathrm{Fe}, 100 \mathrm{mg}\left(\mathrm{FeSO}_{4} \cdot \mathrm{H}_{2} \mathrm{O}\right) ; \mathrm{Zn}, 100 \mathrm{mg}\left(\mathrm{ZnSO}_{4}\right) ; \mathrm{Cu}, 100$ $\mathrm{mg}\left(\mathrm{CuSO}_{4} \cdot 5 \mathrm{H}_{2} \mathrm{O}\right) ; \mathrm{l}, 0.3 \mathrm{mg}(\mathrm{KI}) ; \mathrm{Se}, 0.3 \mathrm{mg}\left(\mathrm{Na}_{2} \mathrm{SeO}_{3}\right)$. 
Table 3. Analyzed chemical composition of diets used in Exp. 1 (\% as-fed basis) $)^{1)}$

\begin{tabular}{lccc}
\hline \multirow{2}{*}{ Item } & \multicolumn{3}{c}{ Source of barley } \\
\cline { 2 - 4 } & Australia & France & Canada \\
\hline Dry matter & 89.28 & 88.78 & 88.45 \\
Gross energy (MJ/kg) & 15.66 & 15.57 & 15.61 \\
Crude protein & 9.35 & 9.54 & 10.52 \\
Neutral detergent fiber & 18.94 & 23.08 & 20.96 \\
Acid detergent fiber & 4.76 & 5.30 & 4.59 \\
Ether extract & 2.43 & 3.02 & 2.47 \\
Ash & 4.41 & 4.58 & 4.88 \\
Calcium & 0.66 & 0.71 & 0.65 \\
Total phosphorus & 0.61 & 0.62 & 0.63 \\
\hline
\end{tabular}

${ }^{1)}$ Analyses conducted in duplicate.

$-20^{\circ} \mathrm{C}$ until needed for analysis [7]. At the end of the experiment, feces and urine were thawed, pooled by pig, homogenized and sub-sampled. Before analysis, fecal subsamples were dried for $72 \mathrm{~h}$ in a $65^{\circ} \mathrm{C}$ drying oven and ground through a 1-mm screen.

\section{Experiment 2}

Exp. 2 was conducted to determine the apparent ileal digestibility (AID) and standardized ileal digestibility (SID) of crude protein $(\mathrm{CP})$ and AA in the barley from the three sources. Eight crossbred barrows (initial BW: $30.9 \pm 1.8 \mathrm{~kg}$; Duroc $\times$ Landrace $\times$ Yorkshire), fitted with a T-cannula in the distal ileum, were allotted to a replicate $3 \times 4$ Youden Square designed experiment with three periods and four diets. Each test period lasted $9 \mathrm{~d}$, with a 7-d adaption to the diets followed by a 2-d collection of ileal digesta from $08: 00 \mathrm{~h}$ to $17: 00 \mathrm{~h}$ using the procedures described by Stein et al [8]. The diets included one nitrogen-free diet which contained $68.9 \%$ cornstarch and $20 \%$ sucrose and three test diets which were formulated to contain $96.6 \%$ of the barley grain from each location as the sole source of AA (Table 2). Two pigs received each diet during each test period. The $\mathrm{N}$-free diet was used to determine the endogenous losses of nitrogen. Chromic oxide $(0.30 \%)$ was used as an indigestible marker in all diets to determine AA digestibility using the indicator method. The analyzed AA composition of the experimental diets is shown in Table 4.

Pigs were equipped with a simple T-cannula near the distal ileum using the procedures described by Stein et al [8]. Pigs were weighed at the beginning of each period and supplied with feed at a level of $4 \%$ of their BW [9]. Two equal-sized meals were provided daily at 08:00 and 17:00. The digesta was collected in a plastic bag and then stored at $-20^{\circ} \mathrm{C}$. Ileal digesta samples were thawed, mixed within animal and diet, and a sub-sample obtained. The digesta sub-samples were lyophilized in a vacuumfreeze dryer (Tofflon Freezing Drying Systems, Minhang District, Shanghai, China) and ground through a 1-mm screen for further chemical analysis.

\section{Chemical analysis}

The dry matter (DM, method 934.01), ether extract (EE, method
Table 4. Analyzed chemical composition of the experimental diets used in Exp. 2 (\% as-fed basis) $)^{11}$

\begin{tabular}{lcccc}
\hline \multirow{2}{*}{ Item } & \multicolumn{3}{c}{ Source of barley } & N-free \\
\cline { 2 - 4 } & Australia & France & Canada & diet \\
\hline Dry matter & 88.88 & 89.21 & 88.62 & 90.42 \\
Crude protein & 9.42 & 9.56 & 10.38 & 0.24 \\
Indispensable amino acids & & & & \\
$\quad$ Arginine & 0.43 & 0.36 & 0.45 & - \\
Histidine & 0.15 & 0.13 & 0.16 & - \\
Isoleucine & 0.30 & 0.26 & 0.34 & - \\
Leucine & 0.61 & 0.55 & 0.68 & - \\
Lysine & 0.36 & 0.35 & 0.39 & - \\
Methionine & 0.09 & 0.09 & 0.08 & - \\
Phenylalanine & 0.41 & 0.39 & 0.48 & - \\
Threonine & 0.32 & 0.30 & 0.35 & - \\
Tryptophan & 0.11 & 0.11 & 0.12 & - \\
Valine & 0.39 & 0.37 & 0.46 & - \\
Dispensable amino acids & & & & \\
Alanine & 0.36 & 0.36 & 0.38 & - \\
Asparagine & 0.57 & 0.53 & 0.61 & - \\
Cysteine & 0.21 & 0.19 & 0.22 & - \\
Glutamine & 1.84 & 1.82 & 2.16 & - \\
Glycine & 0.37 & 0.37 & 0.39 & - \\
Proline & 1.03 & 0.94 & 1.20 & - \\
Serine & 0.38 & 0.37 & 0.43 & - \\
Tyrosine & 0.24 & 0.18 & 0.25 & - \\
\hline Anayses & & & & \\
\hline
\end{tabular}

${ }^{1)}$ Analyses conducted in duplicate.

920.39), CP (method 990.03), $\beta$-glucans (methods 995.16), ash (method 942.05), Ca (method 985.01), and P (method 985.01) percentages of the diets and barley samples were determined according to the procedures of the AOAC International (2005). Neutral detergent fiber (NDF) and acid detergent fiber (ADF) were determined using fiber bags (Model F57; Ankom Technology, Macedon, NY, USA) and a fiber analyzer (ANKOM200 Fiber Analyzer; Ankom Technology, USA) following an adaptation of the procedure as described by Van Soest et al [10]. The concentration of NDF was analyzed using heat-stable $\alpha$-amylase and sodium sulfite without correction for insoluble ash. Total dietary fiber (TDF) and insoluble dietary fiber (IDF) were analyzed according to the procedures of AOAC (method 992.16; AOAC International, 2005). The gross energy (GE) of feces, urine, diets, and barley samples were measured using an automatic isoperibol oxygen bomb calorimeter (Parr 1281 Calorimeter; Parr Instrument Company, Moline, IL, USA). Total starch was analyzed according to the enzymatic method described by Xiong et al [11].

Samples of barley, diets and ileal digesta were analyzed for their AA content. With the exception of methionine, cysteine and tryptophan, the AA content was determined after hydrolysis with $6 \mathrm{~N} \mathrm{HCl}$ at $110^{\circ} \mathrm{C}$ for $24 \mathrm{~h}$ using an AA Analyzer (Hitachi L-8900, Tokyo, Japan). Methionine and cysteine were determined as methionine sulphone and cysteic acid using an AA Analyzer (Hitachi L-8900, Japan) after cold performic acid oxidation overnight and hydrolyzing with $7.5 \mathrm{~N} \mathrm{HCl}$ at $110^{\circ} \mathrm{C}$ 
for $24 \mathrm{~h}$. Tryptophan was determined using high performance liquid chromatography (Agilent 1200 Series, Santa Clara, CA, USA) after $\mathrm{LiOH}$ hydrolysis for $22 \mathrm{~h}$ at $110^{\circ} \mathrm{C}$. The chromium concentration in diets and ileal digesta were determined using a polarized Zeeman Atomic Absorption Spectrometer (Hitachi Z2000, Japan) after nitric acid-perchloric acid wet ash sample preparation [12].

\section{Calculations}

In Exp. 1, the apparent total tract digestibility (ATTD) of GE as well as the DE and ME content in the 3 diets was calculated according to equations obtained from Kong and Adeola [6]:

$$
\begin{aligned}
& \operatorname{DE}(\mathrm{MJ} / \mathrm{kg} \mathrm{DM})=\left(\mathrm{GE}_{\mathrm{I}}-\mathrm{GE}_{\mathrm{F}}\right) / \mathrm{DMI} \\
& \operatorname{ME}(\mathrm{MJ} / \mathrm{kg} \mathrm{DM})=\left(\mathrm{GE}_{\mathrm{I}}-\mathrm{GE}_{\mathrm{F}}-\mathrm{GE}_{\mathrm{U}}\right) / \mathrm{DMI}
\end{aligned}
$$

Where $\mathrm{GE}_{\mathrm{I}}, \mathrm{GE}_{\mathrm{F}}$, and $\mathrm{GE}_{\mathrm{U}}$ are $\mathrm{GE}$ intake, output in feces, and output in urine $(\mathrm{MJ} / \mathrm{d})$, respectively; DMI is dry matter intake ( $\mathrm{kg} / \mathrm{d})$.

Barley was assumed to be the only source of energy in the diet as the slight contribution of energy from the vitamin and mineral premix (3.1\%) was assumed to be negligible. The DE and ME contributed by each barley was calculated by dividing the total by 0.969 . The $\mathrm{DE}$ and $\mathrm{ME}$ used in the calculation were apparent measurements because endogenous losses of energy and nutrients were not accounted for [13].

In Exp. 2, barley was the sole source of $\mathrm{CP}$ and $\mathrm{AA}$ in the test diets. Therefore, the AID and SID for AA and CP in the test diets was equal to that of the barley. Values for endogenous losses, AID and SID of CP and AA in the diets were calculated according to equations described by Stein et al [14].

\section{Statistical analysis}

Outliers were tested using the UNIVARIATE procedure (SAS Inst. Inc., Cary, NC, USA). In Exp. 1, the data for the ATTD of $\mathrm{GE}$ and the DE and ME content were analyzed as a completely randomized design using the general linear model procedure (SAS Inst. Inc., USA), with pig as the experimental unit. In Exp. 2, data were analyzed using the MIXED procedure (SAS Inst. Inc., USA). The statistical model for the digestibility values had diet as a fixed effect and period and pig as random effects. Multiple comparisons were conducted using Tukey's method. In all analyses, the differences were considered significant if $\mathrm{p}<0.05$.

\section{RESULTS AND DISCUSSION}

\section{Chemical composition of barley varieties}

As shown in Table 1, the GE and CP content in Canadian barley were numerically greater than those in Australian and French barley. The highest concentration of NDF, ADF, TDF, IDF, and $\beta$-glucan as well as the lowest GE and EE percentage were ob- served in French barley. Variations in fiber content among the barley samples were largely a reflection of the amount of hull in the barley. The GE contents of the French and Australian barleys were similar to the average value reported by NRC [5] while the GE of Canadian barley was greater than the value published in NRC [5]. In addition, the content of EE and ash were higher and the content of CP was lower among the three barley samples in comparison with the respective average values published by NRC [5].

The average values of GE $(n=56), \operatorname{NDF}(n=65), \operatorname{ADF}(n=$ $69)$, and CP ( $n=159)$ in barley were $16.1 \mathrm{MJ} / \mathrm{kg}, 18.5 \%, 5.8 \%$, and $10.8 \%$, respectively. The nutritive values are obtained from the feed nutrient database maintained at the University of Illinois [1]. Fairbairn et al [15] also reported that 5 spring-seeded covered barley varieties grown on the Canadian prairies ranged from 16.2 to $16.3 \mathrm{MJ} / \mathrm{kg}$ in GE (90\% DM), $22.3 \%$ to $25.6 \%$ in NDF (90\% DM), $5.7 \%$ to $7.2 \%$ in $\mathrm{ADF}(90 \% \mathrm{DM}), 11.8 \%$ to $13.6 \%$ in $\mathrm{CP}(90 \% \mathrm{DM}), 1.6 \%$ to $2.4 \%$ in $\mathrm{EE}(90 \% \mathrm{DM})$, and $3.3 \%$ to $3.8 \%$ in $\beta$-glucan, which were greater than the values found in the current study except the GE, EE, and $\beta$-glucan content. Villamide et al [16] observed that eight Spanish barley cultivars including 4 spring cultivars and 4 winter cultivars ranged from 18.1 to 18.6 $\mathrm{MJ} / \mathrm{kg}$ in GE (DM), $11.2 \%$ to $16.5 \%$ in CP (DM) and $3.30 \%$ to $4.40 \%$ in $\beta$-glucan (DM). In addition, the contents of CP, NDF, and ADF in hulled barley variety from Italy [17] were clearly different from the corresponding indexes of barley from Spain [18]. It is possible that barley variety and its growing conditions influence the outcome because these factors may impact its nutritional composition, considering that relatively large variability in the nutritional value of barley has been reported.

The content of all AA were greater in Canadian barley than the other two barleys which is consistent with its higher percentage of CP. However, the CP and AA content of barley samples in the current experiment were lower than that in a Canadian barley cultivar exported to Mexico [19]. Brestenský et al [20] reported that the $\mathrm{CP}$ content of barley was $14.1 \%$ and greater than that in the present study. So, the content of all AA were also higher than that in the three barleys used in the experiment. With the exception of histidine and methionine, the percentages of indispensable AA in the Canadian barley were slightly higher than the data published by NRC [5]. However, the percentages of indispensable AA in Australian and French barleys were similar or even slightly lower than the data published by NRC [5]. This may be attributed to the higher protein content in the Canadian barley cultivar than in the Australian and French barleys used in the present study. The inconsistent nutritive value of barley in the current study may be caused by the fact that the barley samples from each country were mixed by certain varieties and then exported to China. It is comprehensible that the nutrient contents of three barley samples were different with the value of a single barley variety in literatures and the average value recommended by NRC [5]. 
Table 5. Digestible energy (DE) and metabolizable energy (ME) as well as the appearance total tract digestibility (ATTD) of gross energy (GE) in barley obtained from different sources (Exp. 1)

\begin{tabular}{lccccc}
\hline \multirow{2}{*}{ Item } & \multicolumn{3}{c}{ Source of barley } & \multirow{2}{*}{ SEM } & p-value \\
\cline { 2 - 4 } & Australia & France & Canada & & \\
\hline GE intake (MJ/d) & 21.07 & 20.84 & 20.58 & 1.23 & 0.96 \\
GE in feces (MJ/d) & 4.12 & 4.19 & 3.92 & 0.25 & 0.73 \\
GE in urine (MJ/d) & 0.27 & 0.39 & 0.27 & 0.08 & 0.44 \\
DE (MJ/kg DM) & $14.56^{\mathrm{ab}}$ & $14.48^{\mathrm{b}}$ & $14.75^{\mathrm{a}}$ & 0.06 & 0.03 \\
ME (MJ/kg DM) & $14.33^{\mathrm{ab}}$ & $14.13^{\mathrm{b}}$ & $14.52^{\mathrm{a}}$ & 0.09 & 0.03 \\
ATTD of GE (\%) & 80.40 & 79.99 & 80.96 & 0.35 & 0.18 \\
\hline
\end{tabular}

SEM, standard error of the mean.

1) Data are means of 6 observations per treatment.

a,b Within a row, different superscripts indicate a significant difference $(p<0.05)$.

\section{Energy concentration and energy digestibility}

There were no differences in the daily GE intake and the daily loss of GE in feces and urine among pigs fed the three barley grains (Table 5). This is consistent with the results reported by Wang et al [21] who showed that no differences were found in daily balance of gross energy between two barley cultivars with different fiber content. The DE and ME in Canadian barley were higher $(\mathrm{p}<0.01)$ than in French barley and did not differ from the Australian barley. No differences were observed in the ATTD of GE among the three barley samples. A review by Stein et al [1] showed that the DE and ME in 17 and 7 barley samples averaged 12.8 and $12.2 \mathrm{MJ} / \mathrm{kg}$, respectively. These values were lower than

Table 6. The apparent ileal digestibility (\%) of crude protein and amino acids in barleys obtained from different sources fed to growing pigs (Exp. 2) ${ }^{1)}$

\begin{tabular}{lccccr}
\hline \multirow{2}{*}{ Item } & \multicolumn{3}{c}{ Source of barley } & \multirow{2}{*}{ SEM } & p-value \\
\cline { 2 - 4 } & Australia & France & Canada & & \\
\hline Crude protein & 54.7 & 57.3 & 55.5 & 5.12 & 0.87 \\
Indispensable amino & acids & & & & \\
Arginine & 71.5 & 63.5 & 61.0 & 5.52 & 0.20 \\
Histidine & $80.0^{\mathrm{a}}$ & $70.5^{\mathrm{b}}$ & $80.5^{\mathrm{a}}$ & 2.57 & $<0.01$ \\
Isoleucine & $72.8^{\mathrm{ab}}$ & $67.0^{\mathrm{b}}$ & $77.7^{\mathrm{a}}$ & 2.38 & $<0.01$ \\
Leucine & $75.3^{\mathrm{ab}}$ & $71.3^{\mathrm{b}}$ & $80.0^{\mathrm{a}}$ & 2.04 & $<0.01$ \\
Lysine & 64.6 & 62.5 & 66.7 & 3.14 & 0.45 \\
Methionine & 68.4 & 63.5 & 63.0 & 5.83 & 0.60 \\
Phenylalanine & $80.6^{\mathrm{a}}$ & $62.5^{\mathrm{b}}$ & $77.4^{\mathrm{a}}$ & 4.09 & $<0.01$ \\
Threonine & 74.4 & 65.1 & 72.3 & 3.51 & 0.07 \\
Tryptophan & 68.9 & 62.8 & 70.3 & 4.51 & 0.27 \\
Valine & $64.3^{\mathrm{a}}$ & $55.0^{\mathrm{b}}$ & $64.9^{\mathrm{a}}$ & 2.73 & 0.01 \\
Dispensable amino & acids & & & & \\
Alanine & 49.6 & 51.4 & 51.4 & 2.29 & 0.68 \\
Asparagine & $66.8^{\mathrm{a}}$ & $57.4^{\mathrm{b}}$ & $65.5^{\mathrm{ab}}$ & 2.98 & 0.03 \\
Cysteine & $80.2^{\mathrm{a}}$ & $74.9^{\mathrm{b}}$ & $78.6^{\mathrm{ab}}$ & 1.57 & 0.03 \\
Glutamine & $83.4^{\mathrm{a}}$ & $79.5^{\mathrm{b}}$ & $84.0^{\mathrm{a}}$ & 1.36 & 0.02 \\
Glycine & 46.4 & 40.7 & 36.1 & 5.36 & 0.22 \\
Serine & $72.2^{\mathrm{a}}$ & $62.3^{\mathrm{b}}$ & $69.6^{\mathrm{a}}$ & 2.03 & $<0.01$ \\
Tyrosine & $69.3^{\mathrm{ab}}$ & $62.1^{\mathrm{b}}$ & $77.8^{\mathrm{a}}$ & 3.24 & $<0.01$ \\
\hline
\end{tabular}

SEM, standard error of the mean.

${ }^{1)}$ Data are means of 6 observations for all treatments.

${ }^{a, b}$ Within a row, different superscripts indicate a significant difference $(p<0.05)$. the values obtained in the present experiment. The probably reason was that the different sources of barley used in the database maintained at the University of Illinois (http://nutrition.ansci. illinois.edu). An explanation for the differences in the DE and $\mathrm{ME}$ of the three barleys in this study may be that Canadian barley had a higher GE and relatively lower fiber and $\beta$-glucan concentration in comparison with the other two barley samples. There is significant variability in the concentrations of fiber in barley and in general, the greater the percentage of fiber, the less digestible energy is present in the barley [15]. It confirmed the fact that DE and ME levels were higher in Canadian barley in composition with that in French barley.

\section{Digestibility of crude protein and amino acid}

The AID and SID of CP and all AA are shown in Table 6, 7. In the present study, the AID of histidine, phenylalanine and valine in France barley were lower $(\mathrm{p}<0.01)$ than those in Canadian and Australian barley. The SID of histidine, isoleucine, leucine and phenylalanine in Canadian barley were greater $(\mathrm{p}<0.01)$ than those in French barley and did not differ from Australian barley.

The variation in SID of AA among Canadian and French barley can be attributed to different contents of anti-nutritional

Table 7. The standardized ileal digestibility (\%) of crude protein and amino acids in barley from different sources fed to growing pigs (Exp. 2)"

\begin{tabular}{lccccr}
\hline \multirow{2}{*}{ Item } & \multicolumn{3}{c}{ Source of barley } & & \\
\cline { 2 - 4 } & Australia & France & Canada & & p-value \\
Crude protein & 75.9 & 78.5 & 77.9 & 4.48 & 0.83 \\
Indispensable amino acids & & & & \\
Arginine & 80.0 & 73.5 & 69.0 & 5.52 & 0.20 \\
Histidine & $86.3^{\mathrm{a}}$ & $77.6^{\mathrm{b}}$ & $86.1^{\mathrm{a}}$ & 2.57 & 0.01 \\
Isoleucine & $83.8^{\mathrm{ab}}$ & $79.5^{\mathrm{b}}$ & $87.3^{\mathrm{a}}$ & 2.38 & 0.03 \\
Leucine & $86.0^{\mathrm{ab}}$ & $83.1^{\mathrm{b}}$ & $89.6^{\mathrm{a}}$ & 2.04 & 0.04 \\
Lysine & 76.6 & 74.9 & 77.9 & 3.14 & 0.65 \\
Methionine & 81.3 & 79.7 & 76.7 & 5.08 & 0.67 \\
Phenylalanine & $90.0^{\mathrm{a}}$ & $72.2^{\mathrm{b}}$ & $85.4^{\mathrm{a}}$ & 4.09 & $<0.01$ \\
Threonine & 86.8 & 78.4 & 83.6 & 3.51 & 0.11 \\
Tryptophan & 80.3 & 74.6 & 80.9 & 4.50 & 0.35 \\
Valine & $78.6^{\mathrm{a}}$ & $69.9^{\mathrm{b}}$ & $76.9^{\mathrm{ab}}$ & 2.73 & 0.03 \\
Dispensable amino & acids & & & & \\
Alanine & 74.1 & 75.4 & 74.4 & 2.29 & 0.84 \\
Asparagine & 80.1 & 74.6 & 77.9 & 2.32 & 0.12 \\
Cysteine & 89.3 & 84.9 & 87.1 & 1.57 & 0.07 \\
Glutamine & 88.4 & 84.5 & 88.3 & 1.36 & 0.04 \\
Glycine & 73.6 & 83.7 & 76.3 & 4.58 & 0.13 \\
Serine & $81.1 \mathrm{a}$ & $71.6^{\mathrm{b}}$ & $77.6^{\mathrm{a}}$ & 2.03 & $<0.01$ \\
Tyrosine & $79.8^{\mathrm{ab}}$ & $76.0^{\mathrm{b}}$ & $87.9^{\mathrm{a}}$ & 3.24 & 0.02 \\
\hline
\end{tabular}

SEM, standard error of the mean.

1) Data are means of 6 observations for all treatments; Values for standardized ileal digestibility were calculated by correcting values for apparent ileal digestibility for basal ileal endogenous losses and the basal ileal endogenous losses were determined $(\mathrm{g} / \mathrm{kg}$ dry matter intake) as crude protein, 31.63 ; arginine, 0.41 ; histidine, 0.18 ; isoleucine, 0.37 ; leucine, 0.73 ; lysine, 0.49 ; methionine, 0.13 ; phenylalanine, 0.43 ; threonine, 0.44 ; tryptophan, 0.14 ; valine, 0.62 ; alanine, 0.98 ; aspartic acid, 0.85 ; cysteine, 0.22 ; glutamic acid, 1.03; glycine, 1.78; serine, 0.38 ; tyrosine, 0.28 .

a,b Within a row, different superscripts indicate a significant difference $(p<0.05)$. 
factors present in barley, including $\beta$-glucans (mixed-linked nonstarch polysaccharides) and NDF [22,23]. Jondreville et al [24] observed that $\beta$-glucan in barley may restrict the access to intracellular nutrients or raise the viscosity of the luminal content, and thereby limit the physical exposure of substrates to the digestive enzymes and to the intestinal wall. The SID values from this study were comparable to those reported by Sauvant et al [13]. In comparison with the Canadian barley, most of the SID of AA in French barley were lower, presumably because the elevated level of $\beta$-glucans increases digesta viscosity, which reduces interactions between nutrients and the digestive enzymes [25] and interferes with digestion or absorption of nutrients along the alimentary tract [26].

The French barley sample, with a lower content of $\mathrm{CP}$ and a higher fiber content, also had a lower AID and SID for most AA. This result may be due to differences in dietary fiber content among the barley samples, which can influence the endogenous loss of AA and AA digestibility [27]. Schulze et al [28] observed that AA digestibility could be reduced by increasing dietary NDF content. In addition, the presence of high levels of indigestible fiber in the diet reduced the ability of fiber, AA and peptides to be absorbed in the gastrointestinal tract and thus decrease the digestibility of protein and AA in pigs [29,30].

In conclusion, there were relevant differences among barleys obtained from the three countries in their chemical composition, energy content and the SID and AID of AA. The results from this research suggest that the feeding value of barleys from Canada and Australia are superior to those obtained from France.

\section{CONFLICT OF INTEREST}

We certify that there is no conflict of interest with any financial organization regarding the material discussed in the manuscript.

\section{ACKNOWLEDGMENTS}

The authors express appreciation for the support from the National Natural Science Foundation of China (No. 31372316) and the 111 project (B 16044).

\section{REFERENCES}

1.Stein HH, Lagos LV, Casas GA. Nutritional value of feed ingredients of plant origin fed to pigs. Anim Feed Sci Technol 2016;218:33-69.

2.Statista. Global Grain Production from 2008/2009 to 2014/2015 [Internet]. c2015 [cited 2015 Nov 29]. Available from: http://www. statista.com/statistics/271943/total-world-grain-production-since2008-2009/

3.Stein HH, Kim SW, Nielsen TT, Easter RA. Standardized ileal protein and amino acid digestibility by growing pigs and sows. J Anim Sci 2001;79:2113-22.

4.Pedersen C, Boersma MG, Stein HH. Energy and nutrient digestibility in NutriDense corn and other cereal grains fed to growing pigs. J Anim Sci 2007;85:2473-83.

5.Committee on Nutrient Requirements of Swine, National Research Council. Nutrient requirements of swine. 11th ed. Washington, DC: National Academy Press; 2012.

6.Kong C, Adeola O. Evaluation of amino acid and energy utilization in feedstuff for swine and poultry diets. Asian-Australas J Anim Sci 2014;27:917-25.

7.Ayoade DI, Kiarie E, Neto T, Trinidade Neto MA, Nyachoti CM. Net energy of diets containing wheat-corn distillers dried grains with solubles as determined by indirect calorimetry, comparative slaughter, and chemical composition methods. J Anim Sci 2012;90:4373-9.

8.Stein HH, Shipley CF, Easter RA. Technical note: a technique for inserting a T-cannula into the distal ileum of pregnant sows. J Anim Sci 1998;76:1433-6.

9.Li ZC, Wang XX, Guo PP, et al. Prediction of digestible and metabolisable energy in soybean meals produced from soybeans of different origins fed to growing pigs. Arch Anim Nutr 2015;69:473-86.

10. Van Soest PJ, Robertson JB, Lewis BA. Methods for dietary fiber, neutral detergent fiber, and non-starch polysaccharides in relation to animal nutrition. J. Dairy Sci 1991;74:3583-97.

11. Xiong Y, Bartle SJ, Preston RL. Improved enzymatic method to measure processing effects and starch availability in sorghum grain. J Anim Sci 1990;68:3861-70.

12. Li QY, Piao XS, Liu JD, et al. Determination and prediction of the energy content and amino acid digestibility of peanut meals fed to growing pigs. Arch Anim Nutr 2014;68:196-210.

13. Sauvant D, Perez JM, TranG. Tables of composition and nutritional value of feed materials: pig, poultry, sheep, goats, rabbits, horses, and fish. In: Sauvant D, Perez JM, Tran G, editors. Paris, France: Netherlands and INRA; 2004. pp. 304-9.

14. Stein HH, Seve B, Fuller MF, Moughan PJ, de Lange CF. Invited review: Amino acid bioavailability and digestibility in pig feed ingredients: terminology and application. J Anim Sci 2007;85:172-80.

15. Fairbairn SL, Patience JF, Classen HL, Zijlstra RT. The energy content of barley fed to growing pigs: Characterizing the nature of its variability and developing prediction equations for its estimation. J Anim Sci 1999;77:1502-12.

16. Villamide MJ, Fuente JM, de Ayala PP, Flores A. Energy evaluation of eight barley cultivars for poultry: effect of dietary enzyme addition. Poult Sci 1997;76:834-40.

17. Prandini A, Sigolo S, Giuberti G, et al. Effect of replacing corn with hulled and hulless or low-amylose hulless barley varieties on growth performance and carcass quality of Italian growing-finishing pig. J Anim Sci 2015;93:598-605.

18. Joven M, Pintos E, Latorre MA, et al. Effect of replacing barley by increasing levels of olive cake in the diet of finishing pigs: Growth performances, digestibility, carcass, meat and fat quality. Anim Feed Sci Technol 2014;197:185-93.

19. Mariscal-Landin G, Rodriguez JEL, de Souza TCR. Evaluation of hulless barley as feed ingredient in growing-finishing pigs diets: amino acid ileal digestibility. Anim Feed Sci Technol 2005;120:169-76. 
20. Brestenský M, Nitrayová S, Patráš P, Heger J. Standardized ileal digestibilities of amino acids and nitrogen in rye, barley, soybean meal, malt sprouts, sorghum, wheat germ and broken rice fed to growing pigs. Anim Feed Sci Technol 2013;186:120-4.

21. Wang HL, Shi M, Xu X, et al. Partial dehulling increases the energy content of barley fed to growing pigs and can be comparable to corn. Asian-Australas J Anim Sci 2017;30:562-8.

22. Fan MZ, Sauer WC. Determination of apparent ileal amino acid digestibility in barley and canola meal for pigs with the direct, difference, and regression methods. J Anim Sci 1995;73:2364-74.

23. Lahaye L, Garnier P, Thibault JN, Sève B. Technological processes of feed manufacturing affect protein endogenous losses and amino acid availability for body protein deposition in pigs. Anim Feed Sci Technol 2004;113:141-56.

24. Jondreville C, van Den Broecke J, Gatel F, et al. Ileal digestibility of amino acids and estimates of endogenous amino acid losses in pigs fed wheat, triticale, rye, barley, maize and sorghum. Anim Res 2001;50: 119-34.

25. Kim JC, Hansen CF, Mullan BP, Pluske JR. Nutrition and pathology of weaner pigs: Nutritional strategies to support barrier function in the gastrointestinal tract. Anim Feed Sci Technol 2012; 173:316.

26. Bach Knudsen KE, Hedemann MS, Lærke HN. The role of carbohydrates in intestinal health of pigs. Anim Feed Sci Technol 2012;173: 41-53.

27. Sauer WC, Mosenthin WC, Ahrens F, den Hartog LA. The effect of source of fiber on ileal and fecal amino acid digestibility and bacterial nitrogen excretion in growing pigs. J Anim Sci 1991; 69:4070-4077.

28. Schulze H, van Leeuwen P, Verstegen MW, et al. Effects of level of dietary neutral detergent fiber on ileal apparent digestibility and ileal nitrogen losses in pigs. J Anim Sci 1994;72:2362-8.

29. Jondreville C, van Den Broecke J, Delpech A, et al. Factors influencing the ileal digestibility of amino acids from cereals in the pig. Journees Rech Porcine en France 1994;26:251-8.

30. Mitaru BN, Blair R, Reichert RD, Roe WE. Dark and yellow rapeseed hulls, soybean hulls and a purified fiber source: Their effect on dry matter, energy, protein, and amino acid digestibilities in cannulated pigs. J Anim Sci 1984;59:1510-9. 